\title{
Medyatik Bir Çalışma Alanı Olarak Eleştirel Söylem Çözümlemesi (Televizyon Dizileri Örneğinde)
}

\author{
Levent Doyuran (Öğr. Gör. Dr.) \\ Kırgızistan-Türkiye Manas Üniversitesi Yabancı Diller Fakültesi \\ lev_doy@yahoo.com
}

Başvuru Tarihi: 05.12.2017

Yayına Kabul Tarihi: 20.06.2018

Yayınlanma Tarihi: 30.07.2018

\section{Öz}

Eleştirel söylem çözümlemesi karşılıklı diyalog veya tek bir söylem ya da metin üzerinde anlamı, mesajı, sistematik bir çözümleme ile ortaya koyma çalışmasıdır. Söylem, genel itibariyle tarihi, siyasi, ideolojik, toplumsal, sosyokültürel bir yapı arz eder. Bu nedenle de eleștirel söylem çözümlemesi söylemin dildışı sosyal yapısına odaklanır. Eleştirel söylem analizi söylemde anlatılmak istenen, saklı olanı ortaya koymaya çalışır. Bu nedenledir ki söylemin diliçi özelliklerinden ziyade dildışı bağlamlarını tespit etmek çözümlemenin temelini oluşturur. Çözümleme söylem, anlam, bağlam, yorum, sonuç/sosyal çözümleme çerçevesinde gelişen bir süreçtir.

$\mathrm{Bu}$ çalışmada söylem, görsel göstergeler dışarıda tutularak dikkate alınmaktadır. Söylem ve söylemin genel yapısı (anlam, yorum, bağlam, ideoloji), eleştirel söylem analizi ile ilgili teorik yaklaşımlar ve çözümleme sürecine yönelik analitik yapı çalışmanın genel çerçevesini oluşturmakta ve örnek bir çözümleme sunulmaktadır. $\mathrm{Bu}$ çalışmada eleştirel söylem çözümlemesine ilişkin sistematik bir süreci ortaya koymak hedeflenmektedir.

Anahtar kelimeler: Söylem, eleştirel söylem çözümlemesi, tv dizisi, işkence, siyasi, ideolojik. 


\title{
Critical Discourse Analysis as A Mediatic Working Area (For Example, in Television Series)
}

\author{
Levent Doyuran (Lect. Dr.) \\ Kyrgyz-Turkish Manas University School of Foreign Languages \\ lev_doy@yahoo.com
}

Date Received: 05.12.2017

Date Accepted: 20.06.2018

Date Published: 30.07.2018

\begin{abstract}
Critical discourse analysis is the method of revealing the message and hidden meaning of a mutual dialogue, text or a single discourse with the help of systematic analysis. Discourse, as a rule has historical, political, ideological, social, and sociocultural structure. Therefore, critical discourse analysis focuses on extra linguistic social structure of discourse. Critical discourse analysis attempts to reveal what is hidden in the discourse. For this reason, the basis of analysis is to identify the extra linguistic aspects of the discourse rather than linguistic aspects. Analysis is a process that develops in the frame of discourse, meaning, context, interpretation, result/social analysis.

In this research discourse is considered as an absolute discourse that is discourse itself other than visual sign. Discourse and its general structure (meaning, interpretation, context, and ideology), theoretical approaches to critical discourse analysis and analytic structure of process analysis form the general structure of the research. Besides example of discourse analysis is given. In this study, it is aimed to reveal a systematic process of discourse analysis.
\end{abstract}

Keywords: Discourse, critical discourse analysis, tv serial, torture, political, ideological. 


\section{Giriş}

Türk Dil Kurumu Türkçe Sözlük'te söylem, '1. söyleyiş, söyleniş, telaffuz 2. İfade, kalıplaşmış, klişeleşmiş söz' olarak geçmektedir (TDK, 1998, 2021). Söylem (yazılı ve sözlü), bir takım anlamlarla yüklüdür, bu anlamlar genel itibariyle 'düzanlam' (dilşiçi) ve 'yananlam'lardır (dildışı). Söylemde düzanlam kişide uyandıran ilk çağrışım olup toplumda hemen herkes tarafından anlaşılabilirken yananlam görünenin arkasında veya ötesinde duygusal, toplumsal, kültürel, siyasal vb. içerikler taşır. Yananlamlar, söylemin diğer nesnelerle olan bağlantılarına, sosyal bağlamlarına, benzerliklerine, yakınlıklarına göre kendini gösterir. Bu sebeple de söylem bireyselliğin ve dilsel bir yapının ötesinde dildışı bağlamları içerisinde gizleyen bir kavram olarak değerlendirilebilir. Söylem kavramı, iletişimin en temel unsuru olarak kabul edilen dilin kendine has özellikleriyle birlikte sosyokültürel ve ideolojik bağlamlarıyla kendini gösterir.

Her söylemde ifade edilmek istenen temel bir düşünce, bir mesaj diğer bir ifadeyle ideoloji gizlidir. Eagleton'un $(2011,257)$ da belirttiği üzere "Her söylemsel süreç ideolojik ilişkilere içkindir ve bu ilişkilerin baskısıyla içerden biçimlenir. dilin kendisi. "işçi ve burjuvanın, kadın ve erkeğin, idealist ve materyalistin aynı şekilde paylaştığı, görece özerk bir sistemdir." Söylem ve ideoloji arasındaki ilişkiye vurgu yapan Eagleton'a (2011, 255-257) göre, ideolojiye ilişkin genel yaklaşımlar 'bilinç' ve fikir' düzeyinde olmakla birlikte idealist bir çerçevede ele alınmaktadır. Böylelikle de 'bilinç' söylemsel pratikten kopan bir parça olmaktadır. Eagleton, ideolojiyi ya cisimsiz fikirler olarak ya da sırf belirli davranış kalıplarıyla ilgili bir mesele olarak görme dışında üçüncü bir yol daha olduğundan bahseder ki bu da ideolojinin söylemsel veya göstergesel bir fenomen olarak görülmesidir.

Metnin söylemediğini duyabilmek, anlayabilmek, söylemediği veya söyleyemediği şeyi bulabilmek için metnin de ötesine gidilmesi gerekir (Palmer, 2008, 302) ki bu da, konuyu, olay örgüsünü iyi bilmeyi gerektirir. Metnin söylemediğinin bulunması, metinde anlatılmak istenen veya dolaylı olarak bahsedilenin tespit edilmesi, olayları ve tarihsel süreci bilmekle bağlantılıdır. Bu noktada, metnin anlam ve yorumlanmasının, dilbilgisel çalışmanın ötesinde, sosyal bağlamlar çerçevesinde olduğu söylenebilir.

Söylemin yorumlanması söylemde anlamın ortaya çıkarılması neticesinde başlayan bir süreçtir. Bu süreçte yorumcu söylemde açıkça ortaya konulmayanı, söylenmek isteneni, söylemin kendisinde oluşturduğu çağrıșımlar ve bu sürece kadar elde ettiği verilerle söylemi yeniden inşa eder. Yorumcunun bireysel yaklaşımları söylemi kişisel bir boyuta taşıyabilir. Bir söylemi yorumlamak için büyük çerçeveyi görmek ve ayrıntıları gözden kaçırmamak yorum sürecinin önemli bir bölümü olarak değerlendirilebilir. Bu sebepledir ki söylemde diliçi ve dildışı bağlamlar anlamın ortaya çıkarılması ve yorumlanmasında birer veri niteliğindedirler. Bu bağlamda yorumlama, söylemin yeniden inşa edilmesiyle söylemde yatan gerçeği ortaya çıkarma süreci olarak değerlendirilebilir.

Eleştirel söylem çözümlemesi elde edilen tüm veriler neticesinde ortaya konulan bir çözümleme olarak görülür. Çözümlemenin eleştire olması söylemin sosyokültürel, toplumsal, siyasi, ideolojik bir yapı arz etmesindendir. Fairclough $(2001,20)$, eleştirel söylem çözümlemesini söylemin sosyal ve siyasi iktidar öğelerini tartışan bir çözümleme yöntemi olarak değerlendirir. Aynı zamanda Fairclough (1995, 
98), eleştirel söylem çözümlemesinin üç boyutlu bir çözümleme olduğunu ve bu boyutların metin, yorum ve çözümleme süreci olduğuna dikkat çeker. Fairclough bu çerçeveyle, çözümleme sürecinin temel yapısını ortaya koyar.

Eleştirel söylem çözümlemesi disiplinlerarası bir çalışma alanıdır ve analitik bir çözümleme süreci gerektirir. Fairclough'un da ortaya koyduğu sistematik çözümleme süreci dikkate alınarak daha geniş bir kapsamda analatik bir çözümleme ortaya konulabilir. Bu durumda şu şekilde bir çözümleme süreci öne sürülebilir: 1. Tanımlama (söylem/metin) 2. Olay örgüsü 3. Yorum (çözümleme süreci) 4. Açıklama /sonuç (sosyal çözümleme).

Bu çalışmamızda Türkiye'nin yakın siyasi tarihini konu alan televizyon dizileri örnek olarak ele alınmakta ve bu örnekler üzerinden söylem çözümlemesi yapılmaktadır. Amacımız, televizyon dizileri örneği üzerinden söylem çözümlemesini geniş bir kapsamda ele alarak bir dizi filmde çözümleme sürecini ve nasıl bir yol izlenebileceğini analatik bir çerçevede ortaya koymaktır.

\section{Söylem}

'Söylem', gerek yazılı gerekse sözlü olarak hemen her disiplinde çok sıkça kullanılan bir kavram olarak göze çarpmaktadır. Ekonomi siyaset, dilbilim, sosyoloji, tarih vd. alanlarda 'söylem' kavramıyla çok sık karşılaşmaktayız. Oysa dilbilgisi veya dilbilgisi bağlantılı eserlerde bu kavramla ilgili yeterli derecede açıklayıcı bilgiye rastlanmamaktadır. Dilbilgisel bir temel ve özellik taşıyan söylemin kullanımı itibariyle dilbilgisinin dışında diğer disiplinlerle daha çok bağlantılı olduğu söylenebilir; felsefi söylem, tarihi söylem, iktisadi söylem, iletișimsel söylem, siyasi söylem gibi.

Söylem, karşılıklı iletişimin (yazılı, sözlü, görsel göstergesel; yazar-okuyucu, söyleyen-dinleyici, gösteren-izleyici) temel unsurudur. Bu sebeple de disiplinlerarası bir kavram olarak değerlendirmek mümkündür. Söylemler, dilin kullanımına özgü sistematik bir yapı içerisinde duygularımızın, düşüncelerimizin, fikirlerimizin telaffuz ve ifade ediş biçimleridir.

Latince "discurrere"(oraya buraya koşuşturma, gidiş gelişler) kelimesinden, ve:/veya "uzaklaşma", "eritme", "yayılma" ile discursus kelimesinin muhtelif versiyonlarına karşılık gelir; mecazî anlamında da "özne hakkında uzun uzadıya konuşma", "bir şey hakkında iletişim” anlamına gelir (Sözen, 1999, 19). Kıran, Z, v.d. (2001, 277) söylemi, 'söz', 'metin', 'sözce' kavramlarını içine alan bir terim olarak değerlendirir. "Bu terim 'söz' (F. De Saussure), ya da 'sözce' (L. Bloomfield) kavramlarına göndermede bulunmadığı zaman, öğeleri kendi bağıntılar bütünüyle tanımlanan, bitmiş kapalı bir yapı anlamında aşağı yukarı 'metne' eşdeğerdir."

Wodak'a göre söylem, belli bir olay ile durumlar, kurumlar ve kendisini çevreleyen toplumsal yapılar arasındaki diyalektik ilişkiye işaret etmektedir: Olay; durumlar, kurumlar ve toplumsal yapılar tarafından șekillenmektedir ama aynı zamanda onları da şekillendirmektedir. Bu karmaşık dil ve toplumsal gerçekler ağında çoğunlukla, güç ilişkilerinin etkileri olduğu kadar, dil kullanımındaki kapalı ve gizli ideolojik etkiler de gözlemlenebilmektedir (Wodak et al 2000, Akt: Bedük, 2009, 51).

Sözen'e (1999, 20) göre söylem, Batılı bir felsefenin ürünü olarak gündelik hayatımızda kullandığımız basit dil pratiğidir. Dil kullanımını ise sadece dilbilimin 
gelenekleri (cümle, paragraf, metin vb.) çerçevesinde değerlendirmek yetersiz bir yaklaşımdır. Çünkü söylem, siyasi, kültürel, sosyal ve ekonomik alanlar gibi sosyal hayatın hemen her alanını kapsayan bir yapı arz etmektedir. Sözen, söylemi bir meta-eylem olarak değerlendirir ve bir metin edebi olsun veya olmasin onun üzerinde söylem çalışmasının yapılabileceğini ileri sürer. "Söylem konusunda teorik yaklaşımlar söylemi bir metin gibi, pratik yaklaşımlar ise insanların karşılıklı konuşmalarında ortaya çıkan anlam mübadeleleri olarak görür."

Söylem, belirli kuralları olan ve konuşmalardan oluşan, dilin sistematik düzeni için kullanılan bir kavram olmakla birlikte, bir iletinin tüm boyutlarını, sadece iletinin içeriğini değil, onu dile getireni (kim söylüyor?), otoritesini (neye dayanarak?), dinleyiciyi (kime söylüyor?) ve amacını (söyleyenler söyledikleri ile neyi başarmak istiyor) kapsar. Söylem, belirli bir zaman dilimi içinde belli insan grupları arasında olan ve diğer insan grupları ile ilişkili olarak geliştirilen fikirleri, ifadeleri ve bilgileri içerir. İktidarın uygulanması böyle bir bilginin kullanımına içkindir. Söylem, konuşma ve sohbet de dâhil olmak üzere tüm iletişim biçimlerini kapsar. Bununla birlikte sohbet ve konuşma özel olarak söze dökülen konuşmalarla sınırlı değildir, günlük uygulamalar içinde sosyal dünyayı görme, sınıflandırma ve ona tepki verme yollarını da içerir (Punch'dan 2005, akt: Ekşi ve Çelik, 2008, 100).

Fairclough $(2001,14)$ söylem'i dilin sosyal yapılar tarafından belirlenen bir sosyal uygulama çerçevesinde değerlendirip bu bağlamda kullanılmasını öngörür. Wood ve Kroger (2000: 3) de aynı şekilde dilin sosyal yönüne dikkat çekerek dilin sosyal yapılar tarafından belirlenen bir sosyal uygulama çerçevesinde değerlendirir ve bu bağlamda kullanılmasını öngörür. Phillips ve Cynthia Hardy $(2002,2)$ de aynı şekilde, sosyal hayattaki gerçekliğe dikkat çekmekte ve gerçekliğin söylemle ortaya konulacağını, söylemin sosyal bir gerçekliği ifade eden bir yapı arz ettiğini öne sürer.

Söylem, toplumsal bir pratik olarak karşımıza çıkar. Bu bağlamda taraf veya tarafsızlığın ifadesi, suçlamalar, kültürel alanlardaki insan ilişkilerini yansıtan eylemlerin, pratiklerin sergilenmesi olarak değerlendirilir. İnsanlar günlük yaşamlarındaki tutum, inanç, fikir gibi bir çok konuyu söylem pratikleriyle ortaya koyar. Bu yönüyle de toplumsal bir pratik olan söylem, insanların hayata ilişkin tanımlamaları, anlamlandırmalarında önemli bir rol oynar (Potter, 2004, 71-72).

Sözen'e $(1999,14)$ göre, sessizlik de bir söylemdir. Herhangi bir baskı altında (ekonomik, kültürel, siyasi vb.) bulunan toplumlar baskı devam ettikçe sessizliklerini korur ama bu onların var olmadığı anlamına gelmez. Sessizlik söylemi kaydederken, diyalog sessizliği bozan bir süreç olup söylemi ortaya açığa çıkartır. Bir söylemin kurulması için diyalog şarttır. Diyalog yazar-okuyucu, konuşan-dinleyen arasında anlamın üretilmesine izin veren bir süreç olarak değerlendirilir.

Yapısalcı yaklaşıma göre, söylemler yapısal özellik taşırlar ve her söylemin arkasında her zaman bir yapı bulunmaktadır. Genel itibarıyla, Saussurecü dil sistemini kabul eden günümüz söylem teorileri, bütün söylemlerin arkasında tek ve genel bir sistem olduğu fikrini kabul etmez. Kişisel yorumlarla ortaya çıkan anlamlar veya üretilen anlamlara işaret etmeyen söylemler yapısalcı anlamda, bireylerin varolan bilgi sistemlerini paylaştığını ifade eder. Mübadele edilen anlamlar, katılımcı bireylerin bir özelliği olmaktan ya da onların niyetini yansıtmaktan ziyade, katılımcıların bağlı bulundukları bilgi sisteminin özelliği olmak durumundadır (Sözen, 1999, 48). Barthes $(1996,27)$, yapısalcı görüşün bir metnin söylemi için "anlatı (narrative)" 
kavramını kullandığına dikkat çeker. Anlatıda ise eylemi kararlaştıran kişi değil, söylemdir. Sözen $(1999,48-49)$ ise, yapısalcılıkta her bir anlatının "hikaye ve söylem olmak üzere iki parçası olduğunu öne sürer. Hikâye "anlatının bileșenlerinin ne olduğu", söylem ise "bileșenlerin nasıl oluştuğu" sorusunu yanıtlar. Anlatı içeriği ile iletişime sahne olan anlamlar söylemdir.

Bal (2012: 159) söylem'i, söyleme eyleminin bir sonucu olarak ortaya çıkan dilsel ifadenin sözlü veya yazılı hali olarak değerlendirir. Söyleyen (kaynak), söylenen șeyi ( mesaj) belli bir kanal ile alıcı veya alıcılara ulaştırmak üzere kodlar. Bu kodlama biçimi içinde yaşanılan kültüre, toplumsal gruplara, sınıfsal farklılıklara, eğitime, mesleğe vb. bağlı olarak değişik biçimler arz eder. Bu nedenle de söylem bireysel değil, sosyal bir yapıdadır; söylem birden fazla tarafın varlığını gerekli kıldığı için sosyal bir eylemdir. Söyleme karşı gösterilen tepkiler (duyanlar, okuyanlar) de birer söylem niteliğindedir. Metinsel söylemler (şiir, roman, makale vb.) de diğer metinlerle ilişkili olduğu için metinlerarası iletişimin bir parçası olarak değerlendirilir.

Erbirlik ve Karabulut'a (2015, 47-48) göre söylem, bir bildirişimde gün yüzüne çıkmış olan görülen ve duyulan biçimler ağıdır. Söylem, gramatik olarak cümle ötesi bir birimdir, Sosyolojik olarak ise toplumsal pratik ve uzlașmaya bağlı olarak ortaya konulan etkili söz grubudur. Diğer bir deyişle felsefe, modern ve hermenötik perspektifle üreticisinden (yazar/özne) tecrit edilmiş, genellikle gizli bir ereğe ulaşmak için üstü örtülü ve sadece okuyucusuyla anlamlandırılabilen bir yorumdur. Söylem, belirli bir yerde, belirli bir zaman diliminde ve belirli koșullar altında üretilir ve bu nedenle de tarihseldir. Söylem, iktidarı veya gücü elde etmek, bilinçleri yönlendirmek için kullanılan (episteme) bilgi ve edim söz(dür). Bireyin bastırılmış duygular sonucu ortaya çıkan bilinçdışı ifadeler, dile getirmeler olgusudur. "En nihai anlamında ise iddia ve hüküm içeren önermeler bütünüdür." Erbirlik., Karabulut, 2015, 47-48).

Foucoult söylem'e biraz daha farklı bir yaklaşım sergiler. Foucoult'a göre söylem, kuşkuları üzerine çeken bir özelliğe sahiptir. Bu kuşku veya kaygı yazılı ya da sözlü olarak ortaya konmuş söylemin maddi gerçekliği içerisindeki niteliğinden duyulan kaygıdır. Yani kavgalardan, utkulardan, yaralardan, egemenliklerden, köleliklerden kuşkulanmanın verdiği kaygıdır. Söylemler kendine has özelliğinden dolayı (politik, ekonomik, sosyokültürel vb.). tehlikeli midir? Yani söylerken ya da söyleneni dinlerken niçin kaygılanıyoruz? Nedir bu tehlike? Foucoult, söylemdeki gizli bir noktaya temas ederek söylemin kuşku, kaygı içeriklerini ortaya koymaktadır. Söylemlerde tabusal bir içerik de gizlidir. Yani herkes her şeyi her istediği zaman ve her yerde söyleyemez. İște tabusallık da bu noktada kendini gösterir ve söylem bu yönüyle de aynı zamanda yasaklayıcıdır. (Foucoult, 1987, 23-24).

Söylemle ilgili ortaya konulan yaklaşımlar genel itibarıyla söylemin sosyoloji içerikli bir kavram olduğu, toplumsal bir yapı arz ettiği doğrultusundadır. İletişimin en önemli unsuru olarak dil kendi başına sosyal bir eylemdir. Söylem, dil sistemi kapsamında toplumsal sosyal bir özellik taşır. Duygularımızı ve düşüncelerimizi ilettiğimiz kişi, kişiler veya sosyal gruplara yönelik bir mesaj bir slogan veya bir yorum olarak söylem toplumsal ve sosyal olayların bütününü kapsayan bir ifade şeklidir. Söylemler açık ve net ifadeler taşıyabileceği gibi çok açlk ve net olmayan ifadeler de taşıyabilir. Söylemde herhangi bir konu veya olayla ilgili kodlar gizlidir. Zaman, mekân ve olay örgüsü, ileten ve iletilenin iletişim boyutları çerçevesinde 
bu kodlar ortaya konulmak istenen maksadı ortaya çıkarır. Söylem sıradan değil, özeldir. Her söylem anlam ve mesaj yüklüdür. Söylem bir noktada, söyleyenin olaylara bakışı ( ekonomik, politik, tarihi, kültürel) hayat görüşü, mantalitesini ortaya koyar, bu yönüyle de ideolojik bir yapı arz eder. Yazılı ve sözlü olabileceği gibi görsel göstergeler de birer söylem niteliğindedir. Burada dikkat çeken nokta karşımızdakine anlatmak veya bize anlatılmak istenen bir şeylerin özlü ifadesidir. $\mathrm{Bu}$ anlamda bir sanat eseri de söylem olarak değerlendirilebilir. (Bu tablo size ne anlatıyor, sizde ne çağrıștırıyor? Sorusunda ve verilecek cevaptaki gibi) Bu soruya karşılık ortaya konulan düşünceler, yorumlar söylem olabileceği gibi, jestler mimikler de söylem niteliği taşır (baş sallama, dudak hareketleri, yüz ifadeleri gibi.) Bu yönüyle de 'söylem' toplumun, sosyal hayatın, iletişimin dışında değerlendirilemez.

\subsection{Söylemde Anlam}

Söylemlerde kullanılan sözcüklerin anlamları neyi nerede açıkladıklarına göre yani mekân ve ortama göre değişiklik gösterir. Bir diyalogda söylem veya söylemler bir biriyle zitlaşabilir ve böylelikle değișebilir özellik taşırlar. Örneğin, bir hastanedeki hastaların söylemiyle aynı mekândaki doktorların söylemi zıtlaşabilirya da bir fabrika işçisinin söylemiyle fabrika yöneticilerinin söylemleri arasında bir zıtlık, çelişki olabilir. Fakat kişilerin söylemleri kurumun veya kurumsal söylemi belirlemez. Diğer bir deyişle, doktorların söylemi hastanenin söylemini belirleyemez, ortaya koyamaz. Bu durum bütün kurumsal yapılar (üniversitede, okulda, hapishanede, ailede vs.) için geçerlidir. Söyleme ilişkin dil pratiği tek başına değil diğer söylemlerle bağlantılı olarak ortaya çıkar. Söylem, diğer söylemlerle ilişkilidir ve karşılıklı olarak yeniden üretilmesi söz konusudur. Böyle bir ilişki söylemin hem kendi kendini inşasına hem de diyaloga dayalı inşasına yardımcı olur. "Söylemle karşılıklı etkileşimler olarak değerlendirilebilir: Tıp söylemi, dini söylem medya söylemi gibi. Söylemler, kültürel hayattan, gündelik hayat faaliyetlerine kadar uzanır. Söylemler sosyal gerçeklikleri inşa eder (Sözen, 1999, 25).

Wittgenstein, anlamayı psikolojik bir süreç olarak değerlendirmez. Ona göre anlama, ruhsal bir süreç değildir. Diğer taraftan dil oyunları ve yaşam biçimleri kavramıyla anlamın üretilmesinde öznenin rolüne değinerek kuralın yön gösterici bir levha olduğundan bahseder. Başka bir deyişle, dilin kuralları anlamın ortaya çıkmasında bir yol gösterici niteliğindedir (Akt: Rızvanoğlu, 2012, 54). Sözen'e (1999, 28) göre, saf söylem yoktur. Diğer bir deyişle söylem tarafsız olamaz, subjektivitenin bir ürünü olarak ortaya çıkar. Söylemler, dilin objektif/nesnel durumlarından ziyade sosyal hayatın verileri olarak kendini gösterir ve böylelikle de söylemler sosyal ilişkiler gibi çok boyutlu ilişkiler içerisindedir. Phillips ve Hard'ye (2002, 6) göre, söylemin bir ürünü olan anlam, dil ve gerçeklik arasında bir etkileșim alanı oluşturur. Diğer bir deyişle bir metnin, bir söylemin anlam kazanması için diğer metinlerle veya söylemlerle ve metne anlam kazandıracak üretim ve dağıtım yollarıyla ilişki kurması gerekir. Fiske $(1996,15)$, söylemdeki dilbilgisel özelliklerin ötesinde sosyokültürel bağlam içerisinde ortaya konulan anlam/anlamlara vurgu yapmakta, anlamlandırmanın metindeki göstergelerin, kullanıcının kültürel ve kişisel deneyimiyle etkileşim biçimiyle ilişkili olduğuna dikkat çekmektedir.

Doğan Aksan (2000, 159-160) anlam’ı "Bir sözlükte, bir sözcüğe eklenen öteki sözcükler, bir nesnenin bir dizge içindeki yeri, bir sözcügün duygu değeri, bir nesnenin gelecekteki deneyimlerimiz içindeki pratik sonuçları veya bir simgeyi kullananın gerçekte belirttiği şey” olarak değerlendirir. Aksan, J. R. Fırth’ın "Dildeki 
bir öğenin anlamını, onun öteki birimlerle kurduğu ilişkilerle belirlemekte, birlikte kullanıldığı, bağdaştırıldığı, öteki öğelerle oluşturduğu örgüyle çerçevelendirmektedir." söylemine dikkat çekerek anlamı söylemdeki dilsel görünümün ötesinde diğer birimlerle, öğelerle, ilişkilerle olan bağlantılarında aramak gerektiğini öne sürmektedir. Örneğin:

"Kadın yemek pişiriyor, sonra daireye girecek" söyleminde 'ev ișine, bir kimseye, bir çocuğa bakmak üzere tutulan kadın' anlamı vardır. Aynı şekilde: "Ahmet babayı da öldürdük; iyi adamdı doğrusu!" "Yoo, kalendar adamdı doğrusu" söyleminde bir cinayetten bahsedilmemektedir. Ahmet baba öldü, yani ölümüne tanık olduk anlamı vardır. İkinci söylemdeki Yoo öğesi yok'un konuşma dilinde çok geçen bir biçimi olup olumsuz bir yanıt değil tam tersine bir doğrulama bir onaylama gösterir. Veya "Bu işi on, bilemediniz on beş günde bitirebilirim" söylemindeki bilemediniz ise bilmek eyleminin olumsuz ifadesini değil, 'en çok' 'ya da' gibi bir anlamı yansıtır. Veya "Radyo çok açılmış” dememiz "radyoyu biraz kısıver!” demek yerine geçebilir (Aksan, 2000, 137-138). Verilen örneklerde de görüldüğü üzere söylemlerdeki her kelimenin sözlüksel anlamlarıyla söylemin anlamı ortaya çıkmayabilir. Söylemler, olay örgüsü, bulundukları durum ve şartlara göre farklı anlamlarla yüklü olabilirler.

"Anlama faaliyetinin görevi ise açık/zahir olandan hareketle kapalı/gizli olanı açmaya, metnin söylediklerinden hareketle söylemediklerini keşfetmeye çalışmaktır. Gizli ve kapalı olanın keşfine yönelik bu anlama, yorumcunun metinle kurduğu diyalog aracılı̆̆ıla gerçekleşecektir." (Ebû Zeyd. N. H, 2014, 256).

Anlama veya anlamlandırma işlevi düzanlam ve yananlam olmak üzere iki şekilde değerlendirilebilir: Tek başına bir sözcüğün, ya da göndergesel işlevli bir metindeki sözcüklerin düzanlamlarını vermek; bağlam içinde çağrışımları olan bir sözcüğün yananlam (lar)ını vermek. Sözcükler bağlam içerisinde incelendiklerinde düzanlamı oluşturan anlambirimcik demetleriyle yananlamı oluşturan anlambirimcik demetleri eklemlenerek bir bütün oluştururlar. Bir sözcügün düzanlamı o sözcüğü kullanan dilsel topluluktaki kişiler tarafından anlaşılması kolay olabilir. Yananlamlar ise, düzanlam dizgesinde kendini göstermeyen, gerçekleşmemiş değerleri oluştururlar. Yananlamları bireysel oluşunda ya da sözcüğün kullanıldığı dilsel topluluğun kültürüne özgü duygusal ya da düşünsel boyuttaki deneyimlerinde aramak gerekir (Kıran, Z, v.d, 2001, 235).

\section{a. Düzanlam (Temel Anlam)}

Söylemde düz anlam, diğer bir ifadeyle temel anlam sözlüksel yani kelimelerin sözlükte ifade edilen biçimidir. Bunlar sıfatlar, isimler, nesneler, eylemler olarak sözlük içerisindeki karşılıklarıyla anlamlandırılırlar. Söylemler, bir olay örgüsü çerçevesinde birbirine bağlantılı sözcüklerle kendini gösterir. Düzanlam, söylemin ilk anda oluşturduğu, hemen herkes tarafından bilinen, anlaşılandır. "Burada hava çok soğuk" denildiğinde ilk anlaşılan 'hava' ve 'soğuk' sözcüklerinin sözlüksel anlamlarından ortaya çıkan fiziksel, metorolojik bir anlamdır ve hemen herkes tarafından aynı şekilde anlamlandırılır (hava soğuktur ve üşüyoruzdur). Burada söylemin bütünlüğü söylemde geçen sözcüklerin düzanlamı yani sözlüksel karşılıklarıyla bir anlam kazanır.

Aksan'a (2000, 180-182) göre, “Dilin kullanılışında her birim, bağlama, sözceye, konuya göre, belli ilişkiler içinde belli kavramları yansıtmakta; kimi zaman da yepyeni düşünce ve duyguların aktarıcısı olmaktadır." Aksan, temel anlam'ı, bir ses 
bileşiminin başlangıçta yansıttığı, ilk ve asıl kavram olarak değerlendirir. Örneğin, Türkçede diş'in temel anlamı ' ağzımızdaki sert ve ısırıp koparmaya yarayan organlardan her biri', göz'ün 'görme organı', kızmak eyleminin ise 'ısı verecek kadar sıcaklığı artması', taş göstergesiyle de 'doğadaki sert nesne' anlatılmıştır. Aksan, temel anlam diye belirlenen anlam türünü, sözcügün ilk kullanılışında kurulan bir simge-gönderge ilişkisiyle dış dünyadaki nesneleri, konu ve kavramları dile yansıtan ve deneyimlerimize, mantığa uygun bir takım nitelikleri bulunan, dile özgü bir birim olarak değerlendirir. Kıran'a ( 2001, 235) göre, düzanlam, bir sözcüğün değișmez, nesnel anlamıdır. Yani sözlükte görünen ve o dili kullanan herkes tarafından benimsenmiş nesnel anlamdır. Kırmızı'nın sözlük anlamı bir renk, sonbahar' ın sözlük anlamı bir mevsim gibi. Örneğin "köpek" = canlı « hayvan « memeli « etobur vb...

Söylemin düzanlamı normal şartlarda, söyleyen ve söylenilen (ileten ve iletilen) arasında bir anlam kargaşasına yol açmaz. İletişim halinde olan kişiler veya gruplar hatta bir toplum içerisinde söylemdeki düzanlam anlatılmak istenen değil de direkt ortaya konulandır ve gerek grup gerekse toplum içerisindeki herkes hemen hemen aynı şeyi anlar. Sözlü ve yazılı söylemlerle birlikte görsel göstergeler (fotoğraf, film gibi) de düzanlamsal ifadeler ortaya koyabilir. Bir fotoğrafa baktığımız zaman bizde uyandıran ilk çağrışım bütünlük ifade eden bir görüntüdür. Yani bu fotoğraftaki kişi, örneğin Ahmet'tir ve biz Ahmet'in duruşu, yüz ifadesi, elbisesi veya renk seçimiyle ilgilenmeyiz.

Anlamlandırmada birinci düzey, Saussure'un üzerinde durduğu, çalıştığı düzeydir. Bu düzey, göstergenin göstereni ve gösterileni arasındaki ilişkiyi ve göstergenin dışsal gerçeklikteki göndergesiyle ilişkisini betimler. Barthes, bu düzeyi düzanlam olarak adlandırır. Düzanlam, göstergenin ortak duyusal, aşikar anlamına gönderme yapar. Örneğin, bir sokak manzarası fotoğrafı belirli bir sokağı gösterir; «sokak» sözcüğü binalar arasında uzanan bir şehir yolunu anlatır. Ama aynı sokak renkli bir film kullanılarak veya donuk bir gün ışığı seçilerek yumuşak bir odak ayarıyla çocuklar için mutlu, şefkat dolu bir oyun alanı haline getirilmek suretiyle önemli derecede farklı biçimlerle fotoğraflanabilir. Bunun tam tersi olarak da siyah beyaz bir film, sert odak ayan, güçlü kontrastlar kullanılmak suretiyle aynı sokak oyun oynayan çocuklar için soğuk, zalim, barınılamaz ve yıkıcı bir mekân haline getirilebilir. Bu iki fotoğraf, aynı anda ve birbirine yalnızca birkaç santimetre uzaklıkta iki fotoğraf makinesi tarafından çekilmiş olabilir. Bu iki fotoğrafın düzanlamsal anlamı aynı olacaktır. Farklılığı yaratan yananlamlardır (Fiske, 1996, 116).

\begin{abstract}
Düzanlamlı büyük söylem parçaları, yananlam dizgesinin bir tek birimini olușturabilir (örneğin, birçok sözcükten oluşan, ama yine de bir tek gösterilene gönderen bir betiğin anlatım biçimi). Yananlam, düzanlamlı bildiriyi nasıl kaplarsa kaplasın, onu tüketmez: Her zaman «düzanlam»dan bir şeyler kalır geriye (yoksa söylem olanaksızlaşır). Yananlamlayıcllar hep kesintili, «sapkın»ve kendilerini taşıyan düzanlamlı bildiri tarafindan özümsenmiş göstergelerdir. Yananlam gösterilenine gelince, hem genel, hem bütünsel, hem de dağınık bir özellik taşır. (Barthes, 1979, 89)
\end{abstract}

\title{
b. Yananlam
}

Söylemde yananlam, sözlüksel anlam ile birlikte ve bir olay örgüsü çerçevesinde söylenmek isteneni ortaya koyar. Bu düzanlamda olduğu gibi herkes tarafından bilinmez veya bilinmeyebilir. Yananlam, söylemin içeriğinde yatan, söylemde geçen sözcüklerin oluşturduğu bir bütününde saklı olan gerçektir. Yananlam dilsel öğelerin nesnel anlamlarının dışında sözcüklere yüklenen anlamlardır. Sözcüklere yüklenen 
bu anlamlar söylemin bütünü, diğer bir deyişle genel, büyük çerçeveyi dolayısıyla da büyük çerçevede saklı olan anlamı ortaya çıkarır. Yukarıda verdiğimiz "Burada hava çok soğuk" veya "Buranın havası bozuk" söylemi ikili ilişkilerin zayıf olduğu bir grubun içerisinde veya ortamda kişiler hedef alınarak söylendiğinde (hava durumu nasıl olursa olsun) 'hava' ve 'soğuk' sözcüklerinden metorolojik yani sözlük anlamsal (düzanlamsal) bir ifade değil, 'ortam, mekân' ve 'sinirlilik, iletişimsizlik, sessizlik, ürperti vb.' bir anlam ortaya çıkar. Büyük çerçevede saklı olan ise ortamdan, ilişkilerden duyulan hoşnutsuzluktur. Bu aynı zamanda iletenin iletilene verdiği bir mesaj olarak da değerlendirilebilir.

Yananlamlar, görünenin arkasında veya ötesinde duygusal, toplumsal, kültürel, siyasal vb. içerikler taşıyabilirler. Yananlam söylemde geçen sözlerin veya söylemin bir bütün olarak diğer nesnelerle olan bağlantılarına, sosyal bağlamlarına, benzerliklerine, yakınlıklarına göre kendini gösterir. $\mathrm{Bu}$ bağlamda yananlamın toplumsal bir özellik taşıdığı söylenebilir. Aksan'ın $(2000,180)$ da bahsettiği üzere sözcükler gösterilenlerinin, yansıttıkları kavramların başka nesnelerle benzerlik, yakınlık ya da ilişkilerine bağlı olarak yavaş yavaş çok anlamlı duruma gelmekte, yananlamlar kazanmaktadır. Bununla birlikte, duygu değerleri ve çeşitli tasarımlar da göz önünde bulundurularak sözcüğe bağlanabilir. Yananlamlar, imgelere, öznel izlenimlere vb. ilişkin ikincil kavramlar, duygusal, coşkulu anlamlar olarak değerlendirilebilir. Yananlamlar, bir sözcüğün düzanlamına kullanım sırasında katılır ve iletişimde bulunanların tümünce algılanamaz. Örneğin, kırmızı sözcüğünün yananlamları; ateş, tehlike, komünizm, tutkulu bir aşk vb. olabilir. ... (Kıran, Z., Kıran, A, 2001, 255-256). Fiske, bu görüşü daha ileri bir düzeye götürerek ses tonu, nasıl konuşulduğu, neler söylendiği ve söylenilene ilișkin duyguların, değerlerin yananlamsal ifadeler olduğuna vurgu yapar ve yananlamların bireysel olmaktan ziyade toplumsal olduğuna dikkat çeker (Fiske, 1996, 116-117).

\subsection{Söylemde bağlam}

Söylemde bağlam, önceki söylemler ve olay örgüsüyle ilgili olup aynı zamanda sosyokültürel, tarihi, siyasi örtüşmelerdir. Diğer bir ifadeyle bağlam, söylemin hangi olay veya olaylar çerçevesinde olduğu ve kendinden önceki söylemlerle nasıl bir bütünlük arz ettiğidir. Bağlam, söylenen (iletilen) için anlamın ve yorumun ortaya konulmasında gerçeğe yaklaştırıcı bir sürecin önemli bir parçası olarak değerlendirilebilir. "İletişimin olabilmesinin temel şartı, bağlamdır. En basit bağlam en az kişiyi kapsar. Her iki taraf bu bağlamın temel değişkenlerinin bilgisine belirli oranda sahiptirler. Bazı bakımlardan kişiye özel durumlar olabilir.” (Çakır, 2004, 249)

Vardar (2002, 30), bağlam'ı anlamın kaynağı olarak değerlendirerek anlamın her zaman bağlama ihtiyacı olduğundan bahseder ve anlamla bağlamı eşdeğer tutar. Vardar'a göre bağlam, (context) birinci olarak dil birimini çevreleyen, ondan önce ya da sonra gelen, birçok durumda söz konusu birimi etkileyen, onun anlamını, değerini belirleyen birim ya da birimler bütünüdür ve 'dil içi bağlam' çerçevesinde değerlendirilir. İkinci olarak da duruma, söyleyici ve dinleyicinin dil dışı (toplumsal, kültürel, deneyim ve bilgiler) verilerin bütünüdür. Aydın'a $(2007,86)$ göre ise, 'bağlam' denildiğinde ilk akla gelen veya araştırmacıların, dilbilimcilerin dikkate aldığı 'dil içi' ve 'dil dıșı' bağlamdır. Eğer bir tümce içerisindeki sözcüklerin birbiriyle olan ilişkileri çerçevesinde o sözcüklerin yardımıyla bir anlam çıkarılıyorsa 'iç bağlam', tümcenin kendisi anlamın çıkarılmasına yetmiyor ve bu sebeple de tümce 
dışı unsurlar dikkate alınıyorsa 'dış bağlam' olarak değerlendirilir. 'İnsanların dil kullanımları sosyal bağlamlarda gerçekleşir. Bir söylemde sarfedilen sözcüklerin maddî kapsamları, ancak bir bağlam içinde mübadele edilebilir. Söylemler boşlukta durmaz; bir bağlam içinde gelişir, diğer söylem ve bağlamlarla ilişkiye girer ve dişsallaşır." (Sözen, 1999, 27).

Aksan (2000, 199-200), Türkiye Türkçesinde 'çocuk' sözcüğü (göstergesi) bazı bölgelerin ağızlarında 'çocuk' yerine bala, çaga, bebe, uşak sözcükleri kullanılsa dahi belli bir kavramı yansıttığına değinerek bu öğenin hemen herkes tarafından bilinmesine rağmen ortaya koyduğu kavramın her zaman aynı olmadığına dikkat çeker. Diğer bir ifadeyle, bu gösterge ancak öteki göstergelerle birlikte belli bir kavramı yansıtır. 'Çocuk' göstergesi üzerinden ortaya konulan söylemlerin farklı kavramlar içerebileceklerini Aksan, şu şekilde örneklendirir: "Çocuğu kışta kıyamette başka bir yere tayin etmişler" ya da "Çocuk askere gitti", yahut "Çocuk erken evlendi" denilirse, burada anlatılmak istenen, yetişkin bir insandır. Ama "Çocuk biberonu emip bitirdi" tümcesinde anlatılan, süt bebeğidir; "Çocuk ilkokulun üçünde" sözü ise çocukluk çağındaki insanı anlatır. "Çocuksuz ev" tamlamasıyla açıklanan yine çocuk yaşı içindekilerin olmadığı evdir.

Söylem yazılı veya sözlü bir diyalog veya bir metin olarak karşımıza çıkabildiği gibi bir tek cümleden oluşan bir slogan veya bir reklam, bir deyim veya bir atasözü olarak da karşımıza çıkabilir. Bu durumda söylem içindeki sözcüklerin birbirleriyle olan bağlantıları, sosyokültürel çerçeve ve olay örgüsü dikkate alınır. Çetin, M., vd., (2011:1370), kültürün dildışı bağlamın belirginleşmesinde daha etkili olduğunu ileri sürerler. Argo, deyim, atasözü veya yan (mecaz) anlamların anlaşılmasında dış bağlama gereksinim duyulur. "Buralarda aradığını bulamadı." Düzanlam da olabilir, deyim anlamı da olabilir. "Seninle çıkışta görüşelim." Bir tehdit anlamı mı yaksa bir sözleşme mi? "Ne demek istiyorsun?" Sıradan bir soru mu yoksa tehdit mi? "Ayağını yorganına göre uzat? Düz anlam mı yoksa mecaz anlam mı? Ortaya çıkan bu farklı anlamlar kültür olarak değerlendirilebilir. (Çetin, M vd., 2011, 1370) Aksan, konuya biraz daha açıklık getirmek için örnekleri genişleterek söylemde geçen sözcüğün (göstergelerin) diğer sözcüklerle olan bağlantılarıyla kavram farklılıklarına vurgu yapar. Örneğin, Türkçede kalkmak sözcüğünün ne anlama geldiği sorulduğunda cevap, 'bulunduğu yerden yükselmek' olabilir. Ancak bu anlam sınıfta üç el kalktı ya da perde kalktı, oyun başladı tümcelerinde söz konusudur. (Aksan, 2000, 2002001). Tümcenin anlamı, içinde yer aldığı konuşma zincirine, belli bir metne göre belirlenir. Bu belirleme sırasında durum ve koşullar da etkilidir. Örneğin: "Ben sana klyamam” tümcesi eğer “... ama bu parayı ödemini isteyeceğim” şeklinde sürerse söyleyenin, konuştuğu kimseye kıyabileceği anlaşılır. Ancak "... bu parayı ödemene gönlüm razı olmaz" biçiminde sürerse ilk tümcede belirtilen açıklamanın doğru olduğu, söyleyenin amacının bu olduğu anlaşılır. Diğer taraftan, "Ben sana kıyamam" tümcesinin içinde geçtiği sözcede yorucu bir işi yüklenmekten söz ediliyorsa buradaki kıymak eyleminin anlamı başka, kızı istenen annenin bu konuyla ilgili olarak kızına aynı tümceyi söylediğinde anlamı yine başka olacaktır (Burada "Seni o adama veremem" demek olur.)

\subsection{Söylemde Yorum}

Anlama ve yorumlamayı, güncelliğini koruyan önyargılardan uzak tutmak gereklidir. Çünkü tarihsel bilginin hedefine ancak o konuya dair kişisel fikir ve değerlerden uzaklık ve geçmiş dönemlerdeki fikir ve değerlerin dünyasına tam anlamıyla 
"açık fikirli olma" yoluyla ulaşılabilir. Metnin oluşturduğu ortam, yazarın hisleri ve düşüncesi olarak temelde yorumcu için önemli olmayıp kendi çerçevesinde kastedilen şey olarak önemlidir. Bu bağlamda metnin anlaşılması ve yorumu yazarın şahsı çerçevesinden değil, metin çerçevesinde başlar. Metnin anlaşılması ve yorumu neticesinde, yazarın ortaya koymak istediği (ortaya konulmak istenen, amaçlanan bir durum varsa), amaçladığı nokta açığa çıkarılır. Metnin anlaşılması kişiler arasındaki bir ilişkinin devreye girmesinden dolayı değil, ama metnin anlatmaya çalıștığı ana meseleye katılımdan dolayıdır. Yine bu katılım, bir kişinin kendisini bugünkü dünyaya ait göstermesi için metne izin verirken kendi dünyasından fazlaca dışarıya çıkamayacağına da işaret eder (Palmer, 2008, 237-242).

Yorumbilgisinin kurucusu olarak bilinen Friedrich Daniel Ernst Schleiermacher'e (1768-1834) göre bir metnin yorumu, birbirini tamamlayan iki yordama bağlıdır. Birinci aşama yazarın ve okuyucunun ortak dil çerçevesinde kullandıkları bağlamdan hareketle anlamı ortaya çıkarmayı amaçlayan dilbilgisel yorumlamadır. İkincisi ise metnin kendin özgü yanını açıklamaya çalışan, yani sezgisel ve karşılaştırma yolu ile biçimsel yanın ayırt edici özelliklerini ortaya çıkaran, açıklayan teknik yorumlama. Yorumlama düşünmeye bağlı bir edimdir ve düzanlamsal bir okumanın üzerine yapılacak bir faaliyettir. Düzanlamsal bir okumanın ardından sahip olunmayan olası düşüncenin farkına ve bilincine varmak ise yananlamsal bir iştir. (Günay, 2013, 157). "Yorum faaliyeti dilsel metinlere odaklanır ve metnin dilsel verilerinin analizine dayanır, ancak derin anlamın düzeylerini keşfetmeyi hedefler." (Ebû Zeyd. N. H, 2014, 263)

Söylemin anlaşılması ve yorumlanabilmesi için, kullanılan dilin yapısı ve söylemin odaklandığı olay örgüsünün bilinmesi gerekir. Söylemin anlaşılması ve yorumlanması metnin veya diyalogun yeniden üretilmesi demektir. Bu bağlamda metin, tarihi olaylar çerçevesinde oluşturulmuşsa söz konusu metnin anlaşılması ve yorumlanması, olaylarla ilgili bilgi sahibi olunmayı gerektirir. Kişisel ön yargılar, anlama ve yorumlama sürecinde yönlendirici olabileceğinden, metne kişisel ön yargılarla değil, açık bir görüş ve tarafsız bir yaklaşımla geniş bir perspektiften yaklaşmak gerekir. Diğer taraftan, Eliot'un bahsettiği gibi “Eleștiriyi ön yargıları önleyecek bilgiler üzerine inşa etmek gereklidir. Aynı zamanda neyin tahlil edileceği ve neyin mukayese edileceğinin iyi bilinmesi gerekir." (Eliot, 1983, 62). Nietzsche, yorumun olması gerektiğini, bilimsel bilginin dahi yorumdan soyutlanamayacağına dikkat çekmiştir. Bu durumda, bir olgu ancak yorumla bir olgu olmakta ve gözlem ancak bir yorumlama sürecinde mümkün olabilmektedir. Böylesi bir yorum görüşü ile hareket edildiğinde ve metne uyarlandığında, metnin tümüyle yorumun bir türevi olduğu sonucuna ulaşılabilir. "Metnin kendisinde aslında hiç bir şey yoktur. Ona tüm anlamı veren bizizdir." (Göka, vd., 1999, 277).

Foucoult'ya (1987, 34) göre, söylemin yorumlanmasında hangi teknik kullanılırsa kullanılsın, en sonunda sessizce orada telâffuz edilmiş olanı söylemekten ibarettir. “ Daha önce söylenmiş olan şeyi buna rağmen ilk kez söylemek ve asla söylenmemiş olanı da, öyle olduğu halde usanmadan yinelemek zorundadır." Yorum, metnin kendisinden daha başka bir şeyi söylemeye olanak tanır. Yeni olan söylenen şeyde değil, ama geri dönüşünün gerçekleşmesindedir. Günay’a göre ise, düşünmek bir şeyi yorumlamak demektir. Düşünce ise üç temel öğeye bağlıdır; bilinç, dikkat ve bellek. Düşüncenin ilk öğesi olan bilinç, nesne ile kendisi arasına belli bir mesafe koyarak nesneler üzerinde düşünmek anlamındadır. Düşünce ile nesneler kendi bağlamında tasarlanır ve gerçek yeniden oluşturulur. Dikkat bir şey üzerinde yoğunlaşma ve 
düşünceyi bir yöne yöneltme, bellek ise anımsama işidir. Yorum veya yorumlama işi, kendi düşüncesini doğru anlatabilmek için düşünceyi yeniden düzenlemek, biçimlendirmek veya çevirmek anlamındadır (Günay, 2013, 158-159).

\subsection{Söylemde İdeoloji}

İdeolojik olmayan söylem, söylemsel olmayan ideoloji yoktur. Her ideolojinin/ söylemin anlam inşa mücadelesinde hegemonik iktidar olma olasılığı vardır. Kitle iletişim metinlerinde ideoloji/söylem "toplumsal anlamların belirlenmesi alanındaki mücadele" (Hall, 1998, 166) olarak tanımlanır. İdeolojiyi ya cisimsiz fikirler olarak ya da sırf belirli davranış kalıplarıyla ilgili bir mesele olarak görme dışında üçüncü bir yol daha vardır: Bu da ideolojinin söylemsel veya göstergesel bir fenomen olarak görülmesidir. Bu yaklaşımın eşzamanlı olarak görülmesidir (Eagleton, 2011, 255).

Söylem, belirli kuralları olan ve konuşmalardan oluşan, dilin sistematik düzeni için kullanılan bir kavramdır. Söylem, bir iletinin tüm boyutlarını, sadece iletinin içeriğini değil, onu dile getireni (kim söylüyor?), otoritesini (neye dayanarak?), dinleyiciyi (kime söylüyor?) ve amacını (söyleyenler söyledikleri ile neyi başarmak istiyor) kapsar. Söylem, belirli bir zaman dilimi içinde belli insan grupları arasında olan ve diğer insan grupları ile ilişkili olarak geliştirilen fikirleri, ifadeleri ve bilgileri içerir. İktidarın uygulanması böyle bir bilginin kullanımına içkindir. Söylem, konuşma ve sohbet de dâhil olmak üzere tüm iletişim biçimlerini kapsar. Bununla birlikte sohbet ve konuşma özel olarak söze dökülen konuşmalarla sınırlı değildir, günlük uygulamalar içinde sosyal dünyayı görme, sınıflandırma ve ona tepki verme yollarını da içerir (Punch'dan 2005, akt: Ekşi ve Çelik, 2008, 100).

Eagleton (2011, 28), ideoloji kavramına, bir ifadenin içerdiği dilsel özelliklerden çok, kimin kime hangi amaçlarla ne söylediğiyle ilgili bir mesele olarak yaklaşır. Bu yaklaşımla ideolojinin dil ve dilin içeriği, diğer bir deyişle, söylemle direkt ilişkili olduğu anlaşılmaktadır. Söylemlerdeki dil özelliklerinde değil, söylemin anlamı ve maksadında ideolojik düşüncenin varlığına dikkat çekilmektedir. Eagleton'a (2011, 291) göre, ideoloji bir dil meselesinden çok bir söylem meselesidir; anlamlandırma meselesi değil, somut söylemsel etkiler yaratma meselesidir Althusser, bilimsel söylemler de dâhil olmak üzere, tüm söylemlerin ideolojik içerikli olduğunu savunarak şunları söyler:

\footnotetext{
Bir kelimenin "bir şey belirtmesine" ya da "bir anlam taşımasına" (yani dilin "saydamlığının" apaçıklı̆̆ da dâhil) neden olan apaçıklıklar dâhil, tüm apaçıklıklar gibi sizin ve benim birer özne olmamız "apaçıklığı da" ki bu da hiçbir zorluk çıkarmaz ideolojik bir etki, temel ideolojik etkidir. Dilbilimciler ve değişik amaçlarla dilbilime başvuranlar, bütün söylemlerde bilimsel söylemlerin kendileri de dâhil ideolojik etkilerin hareketinin tanınmamasından doğan güçlüklere takılıp tökezlerler (Althusser, 2000, 61).
}

Köker (2005, 107), 1960'tan itibaren söylem kavramının ele alınışındaki farklılaşmaya değinerek, söylem ve ideoloji arasındaki kavramsal ilişki üzerinde yoğunlaşmadan bahseder. Köker'e göre, söylemdeki konuşma tipleri, toplumsal gruplara ait farklı söylemleri ortaya çıkarır. Söylemlerdeki farklılıklar ve ideolojik pratiklerin söylemsel gücü ise söylem çözümlemesinin sosyal bilimlerle bağlanma noktasını oluşturur.

Her söylem, alıcısı üzerinde bir takım etkiler yaratmayı hedefler ve işe, taraflı bir “özne konumu”ndan başlar. Eski Yunan Sofistleri'yle hemfikir olarak, söylediğimiz her şeyin gerçekte bir retoriksel icra meselesi olduğu ve burada da hakikat ve 
bilme yetisi meselelerinin tam manasıyla ikincil olduğu sonucuna varabiliriz. Eğer bu doğru ise, dilin tamamı "ideolojik" demektir (Eagleton, 2011, 264). Foucault'ya (1972) göre, insanlar sadece söylem sınırlamaları içinde düşünebilirler. Söylem; amaç, geleneksel destekler, güç ilişkilerinin yeniden üretilmesi ve bunların ideolojik etkilerini inşa eden ifade sistemi olarak tanımlanabilir (Elliott, 1996, Akt: Çelik, Ekşi, 2008, 113). "Siyasi, kültürel, iktisadi ve diğer şeyler arasındaki ilişkiler, bizlerin verili tarihsel bağlamlarda bazı özel siyasi hedeflere ulaşmak için tasarladığımız ilişkilerdir ve hiç bir şekilde bizim söylemlerimizden bağımsız olarak var olamazlar." (Eagleton, 2011, 268).

Wodak'a göre söylemde dilin kullanımına bağlı olarak kapalı ve gizli ideolojik güç ilişkilerin etkileri gözlemlenebilmektedir. Wodak, belli bir olay ile durumlar, kurumlar ve kendisini çevreleyen toplumsal yapılar arasındaki diyalektik ilişkilere dikkat çeker: Olay; durumlar, kurumlar ve toplumsal yapılar tarafından şekillenmektedir ama aynı zamanda onları da şekillendirmektedir. (Wodak et al 2000, Akt: Bedük, 2009, 51).

İletişim alanındaki eleştirel yaklaşımlar, farklı araştırma konuları çerçevesinde birbirlerinden ayrılırlar. Bunun nedeni ise ideoloji sorununu ele alış tarzındaki farklılıklardır. Medyametinleri, izleyiciyeilişkin olaraketkinlik/edilginlikbağlamında farklı değerlendirmeleri içerdiklerinden dolayı, eleştirel medya çalışmaları alanında zengin ve hareketli girişimlere kaynak olmuştur ve oluşturmaya da devam edecektir (Dursun, 2014: 27). Bu bağlamda, Çam'a göre, medya çalıșmaları alanında herhangi bir konu ile ilgili düşünce ortaya konulurken karşı düşünceyle birlikte ortaya konulur ve böylelikle bir karşıtlık söz konusu olur. Böylelikle, öne sürülen düşünce, söz konusu karşıtlığın bir tarafına yerleştirilerek değerlendirilir. Bu karşıtlıklar değerlendirilirken bir tarafın diğerine mutlak bir karşıtlığı ve dışladığı varsayılır. "Belli bir söylemin örneğin medya ve ideoloji ilişkisi içinde tahakküm ve direnişi ürettiği düşünülmeksizin, tahakkümün varlığının direnişi dışladığı, dolayısıyla eğer tahakküm ilișkisi vurgulanıyorsa direnișten söz edilemeyeceği ya da en fazla tali bir direnişe değinilebileceği kabul edilmektedir." (Çam, 2006, 206).

Epistemolojik motifli ideoloji kavrayışını benimsemiş medya çalışmaları içinde yer alan pek çok metin kendi perspektifinden belirli bir düşünceyi ortaya koymakla yetinmez. Ortaya atılan düşünce, sıklıkla kendine karşıt olan bir konum belirler, buna işaret eder ve bu karşıt konumu tanımlar ya da adlandırır (Çam, 2006, 94).

\section{Eleştirel Söylem Çözümlemesinde Teorik Yaklaşımlar}

Eleştirel söylem çözümlemesi (EÇS) 1960’lı yıllardan itibaren dilbilimsel bir çalışmanın ötesinde birçok farklı disiplinde uygulanabilen disiplinlerarası bir çalışmadır. Bu bağlamda görsel göstergeler de dâhil olmak üzere sosyal, kültürel, tarihi ve siyasi konularda dilsel (dilbilgisel) bir çözümlemeden ziyade sosyal içeriklerin çözümlenmesine yönelik disiplinlerarası bir çalışma alanı olarak değerlendirmek mümkündür. Eleştirel söylem çözümlemesi Norman Fairclough, Ruth Wodak ve Teun Van Dijk tarafindan ortaya konulup daha çok siyasal ve sosyal alanlarda kuramsal bir çerçeve olarak değerlendirilmiştir.

Eleștirel söylem çözümlemelerinde bir filmde veya bir romanda geçen söylemlerle birlikte sekanslardaki görsel göstergeler, mekânlar, renk seçimleri, havanın sıcak veya soğuk olması, ya da güneşli, yağmurlu, karlı, rüzgârlı, sisli oluşu çözümlemede yardımcı unsurlar olarak değerlendirme kapsamına alınır. Aynı şekilde bir haber 
bülteninde örneğin bir gazete veya $\mathrm{Tv}$ haberlerinde ses tonundan arka planda gösterilen bir film veya bir fotoğrafa kadar hemen her gösterge çözümleme kapsamındadır ve bu kapsamda makro ve mikro yapılar göz önünde bulundurularak bir çözümleme yapılabilir. Fakat görsel göstergeler dışında sadece söylem olarak çözümlenmek istendiğinde diğer bir ifadeyle sadece söylemlerin diğer unsurlar dışarıda bırakılarak çözümlenmesi de mümkündür. Örneğin bir film veya bir romanda veya siyasi bir söyleșide ya da siyasi, sosyal içerikli bir mitingde sadece diyaloglar, söylenenler de eleştirel bir yöntemle çözümlenebilir. Bu tür bir çözümlemede, söylemi gerektiren olay örgüsü, söylemdeki dilbilgisel yapı, söylemin içeriğindeki veya kendinden önceki söylemlerle olan sosyokültürel bağlam dikkate alınır.

Belli bir toplumsal statüde yer alan ve eğitimli olan bir bireyin konuşma biçimi, karşısındaki dinleyicinin toplumsal statüsüne ve eğitimine göre değişiklik gösterir. Bu nedenle çözümleme yapanın söylem türlerine dikkat etmesi gerekir. Böylelikle hem söylem çözümlenir hem de hangi amaçla söylendiği ortaya konur (Rıfat, 2008, 99). Bu noktadan hareketle söylem, dilin kuralları çerçevesinde oluşan semantik bir dilbilimsel sistem iken sentaks, yani anlam, söylemin (cümlenin) semantik yapısıyla örtüşerek, söylemle ortaya konulan düşünceyi açığa çıkaran olarak varsayılabilir. Açığa çıkarılan düşünce cümlenin çözümlenmesiyle gerçekleşir. Çözümleme ise söylemde, doğrudan (direct), ve dolaylı (indirect) ifadeleri ortaya koyar. 'Eleștirel söylem çözümlemesi' genel olarak doğrudan ve dolaylı ifadelerin arkasında gizlenen mesaja odaklanır. Bu mesaj ise olay örgüsü çerçevesinde kim, kime nerede ne maksatla, ne söylüyor? soruları çerçevesinde açığa çıkar.

Analiz, süreçlerle ilgilidir. Süreçler, bir iletişim ortamındaki konuşan-dinleyen ya da okuyanı-yazan kişilere göre belirlenir. Söylem analizi bağlama ilişkin özellikleri ortaya çıkarır. Bu söylem analizinin amacına değil, doğasına ilişkin bir şeydir. Analiz, bir sosyal etkileşim seviyesinde ortaya çıkan herhangi bir maddî formu inceler. Söylem istihdam süreci gibi, mevcut durumdan daha sürekli, dinamik ve bağlamsaldır. Bu yüzden söylem, analiz edildiği anda kesintiye uğrar. Analizin nesnesi, özne ve nesne durumundaki insan ve insana ait olan her şeydir (Sözen, 1999, 99-100).

Eleştirel söylem çözümlemesinde hedef, anlama ulaşma ve ulaşılan anlam üzerinden yorumlamadır. Yapılan yorum söylemde, ortaya konulmak isteneni (mesaj, bilgi, düşünce) içerisinde bulunduğu konum itibariyle (olay örgüsü) değerlendirir ve açığa çıkarır. Eleştirel söylem çözümlemesi geniş bir alanı kapsamakla birlikte daha çok politik ve ideolojik bir çözümleme olmasıyla, söylemle ortaya konulan toplumsal olaylar veya toplumsal sorunların çözümlemesidir. Diğer taraftan, eleștirel söylem çözümlemesi, toplumsal yapının ve iktidar ilişkilerinin metindeki izdüşümünü bulmayı amaçlar. Böylelikle bu yöntemle "(hem dili hem de göstergesel biçimleri; beden dili ya da görsel imgeler) söylem ve diğer toplumsal pratiklerin öğeler arasındaki diyalektik ilişkisi çözümlenir (Fairclough, 2003, 205).

Van Dijk'e (2003, 355) göre, eleştirel söylem çözümlemesi, güç, hâkimiyet, hegemonya, sınıf farkı, cinsiyet, ırk, ideoloji, ayrımcılık, çıkar, kazanç, yeniden inşa, dönüştürme, gelenek, sosyal yapı ya da sosyal düzen gibi temaları ön plana çıkaran ve araştırma alanı olarak bu konuları işleyen söylem çözümlemesi yöntemidir. Fairclough'a (2001: 20) göre ise, eleştirel söylem çözümlemesi, dili sosyal bir eylem biçimi olarak gören ve söylemin sosyal ve siyasi iktidar öğelerini tartışan disiplinler arası bir çözümleme yöntemidir. Diğer taraftan Fairclough, söylem çözümlemesinin 
belli kuralları olmadığına vurgu yaparak araştırmacıların konu bilgilerine göre farklı yorumlar yapabileceklerine dikkat çeker (Fairclough, 1992, 225).

Fairclough ve Wodak (1997) eleştirel söylem çözümlemesinin temel ilkelerini şöyle ortaya koyar :

1. ESC sosyal problemler üzerinde durur.

2. Güç ilişkileri tutarsızdır.

3. Söylem, toplum ve kültürü ortaya çıkarır.

4. Söylem, ideolojiktir.

5. Söylem, tarihidir.

6. Söylem, metin ile toplum arasında aracılık yapar.

7. Söylem çözümlemesi, yorumlayıcı ve açıklayıcı niteliktedir.

8. Söylem, sosyal eylemlerin bir formudur (Akt: Scollon, 2001, 141).

Fairclough, eleştirel söylem çözümlemesini üç boyutlu bir yaklaşımla aşağıdaki şekil üzerinde şöyle göstermektedir:

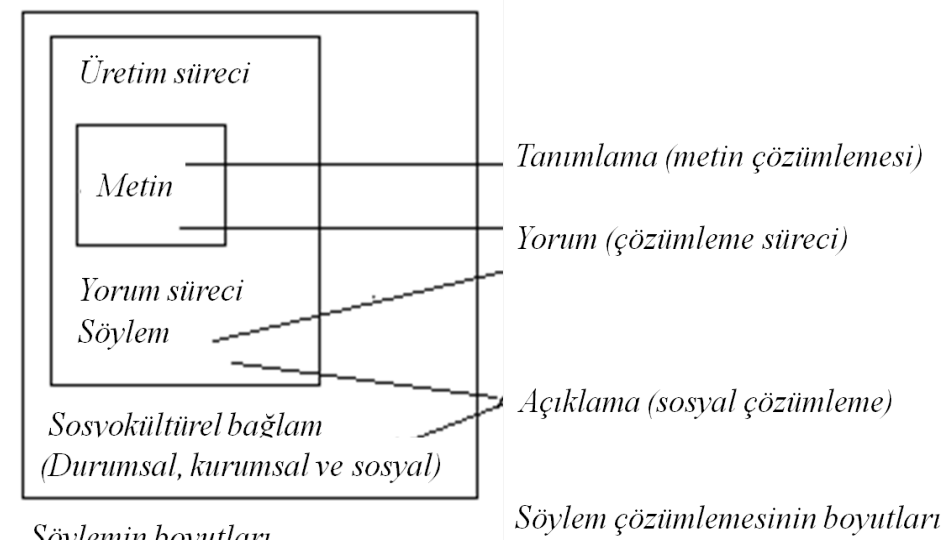

Şekil 1: (Fairclough, N. (1995). Critical Discourse Analysis: The Critical Study of Language. Longman, New York.).

Fairclough'ın söylem çözümlemesi birbiriyle bağlantılı üç aşamadan oluşan, üç boyutlu bir çözümlemedir. Çözümlemenin merkezinde metin vardır. Birinci boyutta metinin ((text; spoken and written) yapısı (kişi, yer, zaman, olay, anlatıcı), metindeki gramatik özellikleri, kullanılan kelimeler ve sözcükler üzerinde durulur. İkinci boyut metindeki söylemlerle metnin yorumlanması (discourse practice; text production and text interpretation) aşamasıdır. Bu aşamada, söylemlerin, birinci aşamadan hareketle (gramatik yapı, seçilen sözcükler, kelimeler) yorumları yapılır. Bu aşamada, çözümleme daha genişletilmiştir, aynı zamanda da çözümlemenin bu boyutu üretim sürecidir. Söylemlerdeki ideolojik, siyasi veya toplumsal ifadeler ortaya konarak yorumlanır. Yani var olan metin yapılan yorumla tekrar inşa edilme sürecindedir. Üçüncü boyut, söylemlerin yorumlanmasıyla elde edilen verilerden hareketle daha geniş bir çerçevede sonuca ulaşma ve açıklama aşamasıdır (sociocultural practice). Bu aşamada verilen söylemlerle ne amaçlanmak istendiği, hangi mesajların verilmek istendiği, söylemlerde yazarın (veya senaristin) siyasi veya ideolojik taraf olup olmadığı, sosyal bir çözümlemeyle açıklama yapılarak ortaya konur (Fairclough, 1995, 98). Fairclough'ın ileri sürdüğü bu üç boyutlu model, eleştirel söylem çözümlemesi için bir çerçeve oluşturur. Bu modele göre, metinlerin diğer metinler ve sosyal bağlam içerisinde çözümlenmesi ilkesine dayandığı görülmektedir. 
Fairclough'ın eleştirel söylem çözümlemesi için ortaya koyduğu analitik çerçeve dikkate alınarak çözümlemenin boyutları genişletilip daha geniş bir çerçevede çözümleme sürecine gidilebilir. Bu süreç eleştirel bir yaklaşım kapsamında olmalıdır. Bir ideolojiye veya bir siyasi görüșe sahip olmak ya da tarihi bir olaya olumlu bir yaklaşım sergilemek bütün bunların kusursuz olduğu anlamına gelmez. Amaç, ortaya konulan söylem hangi olay örgüsü çerçevesinde söylenmiş olursa olsun analitik bir çözümleme süreci çerçevesinde anlatılmak isteneni ortaya çlkarmaktır. Kısacası, Sözen'in (1999, 14) ifadeleriyle, “Söylem üzerine yapılan araştırmalar, analizler birey, toplum ve sosyal gerçeklikler hakkında bilgi edinme yollarından biri olarak anlaşılmalıdır."

Eleştirel söylem çözümlemesinde dört aşamalı bir süreçle çözümlemeye gidilebilir:

1. Tanımlama (söylem/metin): Söylemin dilbilgisel yapı özellikleri olarak değerlendirilebilir. Diliçi bağlamlar incelenir; kelime seçimleri, özne yüklem ilişkisi, söylem olumlu mu, olumsuz mu? Kip özellikleri (istek kipi mi, emir kipi mi vd.?), ünlemler, dolaylı veya dolaysız ifadeler, söylem bir atasözü, deyim veya bir tavsiye niteliğinde mi? gibi bir takım yapısal özellikler incelenir.

2. Olay örgüsü: Söylem her zaman bir olay üzerinedir. Çözümleme sürecinin bu aşaması olay örgüsünün ne olduğu, söylemin hangi olay çerçevesinde söylendiğini tespit etmektir. Olay örgüsünün tespiti dildışı bağlamla ilişkili olup söylemle olay arasındaki bağlantıyı ortaya çıkaracak, bu da anlamın belirginleşmesinde etkili olacaktır. Bu olaylar tarihi, kültürel, siyasal, sosyal, toplumsal veya güncel sıradan olaylar olabilir. Olay bilinmeden söylemi çözümlemek eksik bir çözümleme olmakla birlikte yanlış bir çözümlemeye de götürebilir. Çözümlemede amaç gerçeğe ulaşmaktır. Gerçeğe ne kadar yaklaşılırsa anlam o derece belirginleşecektir. Gerçek ise söylemde saklanan, herkesin göremediğidir.

3. Yorum (çözümleme süreci): Çözümlemenin eleştirel olması yorum sürecinde gizlidir. Çünkü bu süreç bir anlamda söylemin /metnin yeniden inşasıdır. Söylem ile olay örgüsü arasındaki ilişki tespit edilir ve söylem içeriğindeki tarihi, siyasi, sosyal, toplumsal, kültürel bağlamlar, güç ilişkileri ortaya konur. Amaç bizim ne görmek istediğimiz değil, bize neyin gösterilmek, anlatılmak istendiğini tespit etmektir. Biz bu söylemden ne anlıyoruz? Sorusunun cevabı yorumla bütünleştirilerek ortaya konulur. Böylelikle elde edilen veriler ve ortaya konulan yorumla sonuca gidilir.

4. Açıklama /sonuç (sosyal çözümleme): Bu süreç çözümlemede konulacak son aşaması olarak değerlendirilebilir. Tanımlama, olay örgüsü ve yorumla genel bir veri oluşmuştur ve bu verilerle sonuç ortaya konur. Eleştirel söylem çözümlemesi genel anlamda sosyal içeriklidir. Bu nedenle de sonuç 'sosyal çözümleme' olarak da nitelendirilebilir. Bu aşamada, söylem veya söylemlerle (metin) amaç nedir, ortaya konulmak istenen nedir, hangi mesaj veya mesajlar vardır, söylemdeki ideolojik yapı nedir, yazar (veya senarist) taraf mıdır? Net ifadelerle açıklanır.

\section{Eleştirel Söylem Çözümlemesi Örneği}

Eleştirel söylem çözümlemesi hemen hemen tüm disiplinlerde uygulanabilen bir çalışma alanıdır. Bu bağlamda dizi filmler, belgeseller, roman, gazete, dergi vb. gibi kitle iletişim araçları eleştirel söylem çözümlemesi için birer mekândırlar. Eleştirel söylem çözümlemesi bir çalışma alanı olması itibariyle sistematik bir yapı arz eder. Çözümleme tamamen bir dizi filmde geçen örnek söylemler üzerinden 
yapılabileceği gibi bir konu üzerinde birden fazla diziden alınan diyaloglarda geçen söylemler üzerinden de yapılabilir.

Ortak Konu: Türkiye'de darbeler dönemi gözaltı süreçlerinde yaşanılanlar (işkence) “Hatırla Sevgili" (52. Böl.)

Polis Gözaltı Merkezinde:

(Selma'yı da sorgudan sonra bir odaya getirirler. Şule'nin ayakları işkenceden yarılmış, şişmiştir. Selma bu durumu görünce çok şaşırır.)

Selma: Sana ne yapmışlar böyle mikrop kapacak. Bir şeyler yapmak lazım. İlaç filan isteyelim, böyle olmaz. Çok acıyor değil mi?

Şule: Alıştım galiba bilmiyorum. Arada bir doktor gelip pansuman yapıyor.

Selma: Buraya doktor mu geliyor?

Halime: Hep geliyor. Yaraları tedavi ediyor, daha sonrası için.

Selma: Bu doktoru çok merak ettim.

\section{“Bu Kalp Seni Unutur mu?” (2. Böl.)}

Polis Gözaltı Merkezinde:

(Yıldız (solcu) gözaltına alınmış ve işkence görmektedir. Gülümsu da kimliği olmadığından dolayı tutuklanmış ve Yıldız'ın bulunduğu hücreye atılmıştır.)

Gülümsu: (Yıldızın suratına dikkat eder) Yıldız! Ne oldu suratına böyle? Nasıl bir yer burası? Ne oluyor burada?

Yıldız: Bak şimdi beni dinle. Biz buradan uzun süre çıkamayabiliriz tamam mı Gülümssu. Bize yardım etmen lazım.

Gülümsu: Tamam peki nasıl?

Yıldız: Burada ve işkence altında olduğumuzu dışarıdakilere söylemeni istiyoruz. Ayrıca akrabalarına haber vermek isteyen arkadaşlarımız da var.

Diğer kız: Telefon numarası versem arar mısınız? Ailemin burada olduğundan haberi yok.

Yıldız: Dediğim gibi yarın seni bırakırlar hemen Cemile'ye git. Burada olduğumuzu, işkence altında olduğumuzu ona anlat. Hemen babamı arasın. Mutlaka arasın. Şimdi sana bir adres söyleyeceğim onu ezberleyeceksin ve o adresi de Cemile'ye söyleyeceksin tamam mi?

Gülümsu: Neden?

Yıldız: Anlatacağım, iyi dinle. (Bu arada polis gelir ve Yıldız’ın gözlerini bağlayarak götürür.)

Gülümsu: (Şaşkın bakışlarla) Nereye götürüyorlar onu?

Diğer kı: Sorguya

Gülümsu: Bu saatte mi? Işskence yapıyorlar değil mi? (Ağlamaya başlar) Allahım nasıl bir yer burasi ya?

Diğer kız: Önce elektrik veriyorlar, sonra topluca dövüyorlar, sarkıntılık da yapıyorlar, falaka da var. Yıldız ondan öyle yürüyordu. Kocasının yerini soruyorlar. $O$ da boşandık bilmiyorum diyor. Tabi birkaç gün konuşmazsa adamın kaçacağını biliyor polis. Bu yüzden durmadan hirpaliyorlar.

“Çemberimde Gül Oya” (12. Böl.)

Kumaşçı dükkânında:

(Mehmet, Yusuf'un kimliğini almıştır, çıkarken de telefonunu alır. Planı kurduktan sonra onu dükkâna çekmek için kimliğini kaybetmiş olduğunu ve dükkânda düşürdügünü söyleyerek dükkâna çağırır. Yusuf dükkâna geldiğinde Mehmet ve arkadaşları onu yakalayıp bağlarlar.) 
Yusuf (polis): (gülerek) Oyun oynuyorsunuz. Biriniz iyi biriniz kötüyü oynuyor. Tıpkı bizim yaptı̆̆ımız gibi. Toy oğlanlarsınız siz belli. Acemisiniz. Bırakalım bunları bırakalım. Oynamayalım birbirimizle. Ne istiyorsunuz açık açık söyleyin

Mehmet: Konuşmak

Yusuf: Ne olacak konuşunca? Bir şey değişecek mi? Hayattasın, yaşlyorsun işte, ona dua et sen. Ne konuşması? (bağırarak) Sen kimsin ki seninle konuşacağım lan ben! Ne konuşacağım ben sizinle? Beni niye getirdiniz buraya? Ölen arkadaşlarınızın hesabını sormaya mi? Bunların bedelini bana mı ödeteceksiniz aklınız sira!

Mehmet: Bunu anlayamazsın sen. Ben de anlayamadım zaten. (...) Seni buraya gör diye getirdik. Geride bıraktı̆̆ın ya da yok ettiğin hayatları gör diye.

Yusuf: Gözlerim bağlı göremem ki!

Rıdvan: (bir tokat vurarak) Alay etme bizimle!

Mehmet: (Yusuf'u tutarak dükkânın bodrum girişine getirir.) Yürü. Gözlerin kapalı değil mi? (bağırarak) Uzaktan gelen sesleri kestirmeye çalışıyorsun. Kim bunlar? Yüzleri nasıl bu insanların? (...) utancı hisset. Evini düşün, karını düşün, çocuklarını düşün hisset. Hiç mi suçun yok? Bu haksızlı̆̆ hisset.

\section{"Seksenler" (32. Böl.)}

Kahvehanede:

Kırkaltılık: 12 Eylül ihtilali anarşiyi bitirdi ama modern dünyayla ilişkimizi kesti, modern dünyadan bizi uzaklaştırdl.

Berber Recep: Ne diyorsun sen be ne diyorsun? Asıl 12 Eylül oldu, kan durdu asıl şimdi medeni ülke olduk. Sen 12 Eylül öncesine mi dönmek istiyorsun?

Kırkaltılık: Akan kan durmadı Recep usta. Sadece artık biz görmüyoruz. Kan kapalı kapılar ardında hâlâ akmaya devam ediyor.

\section{"Sevda Kuşun Kanadında" (15. Böl.)}

Dış mekânda:

A.Türkeş: Ömer evladım nasılsın?

Ömer: Teşekkür ederim başbuğum. Sağolun.

A.Türkeş: Sen Anadolu çocukları davası için işkence gördün. Belki de bu son olmayacak. Bu ülkü uğruna nice yiğitler ölümlere gögüs gerecek ama sen bugün dik duracaksin ki uğruna mücadele verdiğimiz bu sancak dik duracak eğilmeyecek. Hepiniz, hepiniz birer Türk bayrağısınız. Bu bayrağı kirletmeyin, lekeletmeyin, yere düşürmeyin.

Tanımlama (söylem / metin): Yukarıda, Türkiye'nin yakın siyasi ve toplumsal dönemlerini konu alan televizyon dizilerinden alınan örnek diyaloglarda geçen söylemlerde soru cümleleri, emir kipi ve ünlem ifadeleri yoğun bir şekilde görülmekle birlikte tavsiye, mesaj niteliği de taşımaktadır. Söylemler, heyecan ve korku içerikli olup hem olumlu hem de olumsuz ifadeler yer almıştır. Diyaloglar içinde söylemler bir öncekilerle bağlantılı olup seçilen kelimeler; polis, işkence, ölüm, acı, kan utanç, haksızlık, hesaplaşma, hissetme, modern ülke, modern dünya çerçevesinde yoğunlaştığı görülmektedir.

Olay Örgüsü: Türkiye'de darbeler döneminde gözaltı sürecinde yaşananlar (işkence).

Yorum (çözümleme süreci): Yukarıda verilen örnek dizilerde geçen diyaloglarda darbe süreçleri ve sonrasında gözaltına alınan gençlerin gördüğü işkenceler ve mağduriyetler ortak bir bakış açısıyla dikkatlere sunulmaktadır. Bir taraftan sokak çatışmaları birden kesilirken diğer taraftan gözaltına alınan, tutuklananların durumuna değinilmekle şiddetin mekân değiştirdiğine dikkat çekilmektedir. 
Söylemlerde işkence görenler ve işkence yapanlar net bir şekilde ortaya konulmaktadır. İşkence edilen taraf için masumiyet ön plana çıkarılırken işkence eden devlet görevlileri suçlu olarak değerlendirilmektedir. Bu süreçte işkencenin şiddetine dikkat çekilmekte dişarıdakilerin ise içeridekilerin çektiği acılardan habersiz olduğu, işkence altında olanların ve ailelerinin birbirleriyle iletişim kuramadıklarına vurgu yapılmaktadır. Söylemlerde ortaya konulan ve dikkat çekilen ifadelerde aynı zamanda medya aracılığıyla bir hesaplaşmanın söz konusu olduğu da görülmektedir.

Açıklama/sonuç (sosyal çözümleme): Darbeler süreci ve sonrasında özellikle de 12 Eylül darbesi sonrası işkence mağdurlarının çektiği acılar söylemlerle ifade edilmek suretiyle döneme ait siyasi ve sosyokültürel bağlamda kolektif bellek inșa edilmektedir. "Sana ne yapmışlar böyle mikrop kapacak. Bir şeyler yapmak lazım. İlaç filan isteyelim, böyle olmaz. Çok acıyor değil mi?" "Alıştım galiba bilmiyorum. Arada bir doktor gelip pansuman yapıyor." (Hatırla Sevgili), "Sen Anadolu çocukları davası için işkence gördün..." (Sevda Kuşun Kanadında) söylemleriyle gözaltı süreçlerinde yaşanan işkencelere, "Bu saatte mi? İşkence yapıyorlar değil mi? (Ağlamaya başlar) Allahım nasıl bir yer burası ya?" "Önce elektrik veriyorlar, sonra topluca dövüyorlar, sarkıntılık da yapıyorlar, falaka da var.” (Bu Kalp Seni Unutur mu?) söylemleriyle de işkencenin boyutlarına vurgu yapılmaktadır. Basında da yer alan "Kenan Evren dün yaşamını yitirdi. Bugün yaşı 40'ın altında olanlar için Kenan Evren ve 5 General'in gerçekleştirdiği 12 Eylül 1980 darbesinin bir anlamı olmayabilir. Ama o günleri hatırlayanlar için 12 Eylül darbesi denilince akıllara aylarca süren gözaltılar, gözaltında kayıplar, akıl almaz işkence yöntemleri ve idamlar geliyor." (10-052015 SABAH Gündem) gibi yazılarla darbeler dönemine ait gözaltı süreçlerindeki işkencelerin zaman zaman gündeme alınması, konuyla ilgili hassasiyetin dile getirilmesi kolektif bellek bağlamında dikkat çekicidir. Diğer taraftan Zürcher (2000, 408), özellikle 12 Eylül darbesi akabinde işkencenin çok yaygın olduğu ve rahatlıkla uygulandığından bahsetmektedir. "Uluslar Arası Af Örgütü”, ișkence uygulanmasına ve bunun yol açtığı sonuçlara dikkat çektiği için özellikle 1983 sonrası bazı polis ve subaylar mahkemeye çağrıldılar. "Seni buraya gör diye getirdik. Geride bıraktığın ya da yok ettiğin hayatları gör diye." (Çemberimde Gül Oya) söylemiyle işkence yapan bir polis örneği üzerinden o dönemde işkence yapan polislere (ve diğer görevlilere) bir mesaj verilmekte ve bu durumu hissetmeleri, neler yaptıklarını hatırlamaları ve hatırladıkça acı çekmeleri istenmek suretiyle bir hesaplaşmaya gidilmiștir. "12 Eylül ihtilali anarşiyi bitirdi ama modern dünyayla ilişkimizi kesti."(Seksenler) söyleminde 12 Eylül darbesiyle Türkiye'de modernleşme sürecinin baltalandığı, bir duraklama dönemine girildiğine vurgu yapılarak sosyokültürel bağlamda kolektif bellek inşa edilmektedir. "Akan kan durmadı Recep usta. Sadece artık biz görmüyoruz. Kan kapalı kapılar ardında hâlâ akmaya devam ediyor." (Seksenler) söylemiyle de konu farklı bir boyuta çekilmekte sokaklarda anarşinin durduğu fakat acıların devam ettiğine değinilmektedir. "kapalı kapılar ardında" deyimi bilinmeyene, görünenin arkasında yaşanılan gerçeklere işaret eder. Bu söylemde gözaltına alınanların, tutuklananların maruz kaldığı işkenceler ve ölümlere, idamlara dikkat çekilmek suretiyle kolektif bellek inşa edilmektedir.

\section{Sonuç}

Söylem diliçi bir yapı arz ettiği gibi aynı zamanda dildıșı (sosyokültürel, toplumsal, siyasi ve ideolojik) bir yapı da değerlendirilir. Bu itibarladır ki söylem medyatik, 
sosyal bir kavram olarak karşımıza çıkar. Söylem, ileten, ileti ve iletilen çerçevesinde bir bütünlük arz eder. Söylemler bir olay örgüsü temelinde ortaya konur ve amaç genel anlamda siyasi, ideolojik ve sosyokültürel mesaj niteliğindedir. Söylem tarafsız değildir. Söylemler dilin objektif/nesnel durumlarının ötesinde sosyal hayatın verileri olarak karşımıza çıkar. Bu sebepledir ki çok boyutlu sosyokültürel ilişkiler olarak değerlendirilir.

Söylemler güç-iktidar ilişkileri çerçevesinde bir mücadele alanı olarak değerlendirilebilir. Söyleme dair öne sürülen yaklaşımların genel olarak toplumsal olduğu görülmektedir. Söylemin ideolojik olması da söylemin sosyal bir yapı arz ediyor olmasındandır. Bu bağlamda duygularımızı düşüncelerimizi ilettiğimiz kişi, kişiler veya sosyal gruplara yönelik bir mesaj bir slogan veya bir yorum olarak söylem, toplumsal, sosyal olayların ve konuların bütününü kapsayan bir ifade șekli olarak değerlendirilebilir.

Söylemde anlama ulaşmak dilçiçi ve dildışı bağlamlar bağlamları ortaya koymakla gerçekleşir. Dilçiçi bağlamlar söylemde geçen kelimeler ve söylemin dilsel yapısını ortaya koyarken dișdıșı bağlamlar söylemin bağlantılı olduğu olay örgüsü, toplumsal, sosyokültürel, siyasal bağlamlar olarak değerlendirilir. Bunun yanında söylemler, kendisinden önceki söylemlerle de bir bağ oluşturur ve bu da anlamı ortaya koymada önemli bir unsurdur.

Söylem, diğer söylemlerle ilişkilidir ve karşılıklı olarak yeniden üretilmesi söz konusudur. Böyle bir ilişki söylemin hem kendi kendini inşasına hem de diyaloga dayalı inşasına yardımcı olur. Böylelikle söylemin yorumlanması da söylemin yeniden inşası olarak görülebilir. Yorum metnin kendisinin dışında başka bir şey söylemektir. Burada yeni olan yorumun kendisi değil, yorumla ortaya konulan bir geri dönüşüm olarak değerlendirilir. Diğer taraftan yorumlama bir metnin, bir sözün veya bir mesajın en doğru bir şekilde anlamını ortaya koyma süreci olarak görülebilir.

Söylem üzerine yapılan çalışmalar sosyal bilimler alanında kapsamlı bir çalışma, bir yöntem olarak değerlendirilir. Söylemi, toplumsal ve kültürel bağlamları ve başka söylemlerle bağıntıları içinde değerlendirerek çözümlemeye gitmek gerekir $\mathrm{Bu}$ sebeplede analitikbirçalışmagerektirir.Eleştirelsöylem çözümlemesidisiplinlerarası medyatik bir çalışma alanıdır. Çözümlemedeki amaç söylenmek isteneni iç ve dış bağlamlarla ortaya koymak, söylemde saklı olanı ortaya çıkarmaktır. Diğer bir deyişle, eleştirel söylem çözümlemesinde amaç, anlama ulaşmak ve ulaşılan anlam üzerinden yorum yapmaktır. Yorum, anlatılmak isteneni (mesaj, bilgi, düşünce) içerisinde bulunduğu konum itibariyle (olay örgüsü) değerlendirir ve açığa çıkarır.

Eleştirel söylem çözümlemesinde anlama ve yorumlama süreçleriyle elde edilen verilerden yola çıkarak sonuca gidilir. Çözümlemenin gerçek ya da gerçeğe yakın bir sonucu ortaya koyabilmesi için sistemli bir çalışmaya ihtiyaç vardır. Bu sistemli çalışmada izlenecek yol; söylemin dilsel yapılarını incelemek, söylemin çerçevelediği olay örgüsüne ulaşmak, anlamı ortaya koymak, yorumlamak ve sonuca yani sosyal çözümlemeye gitmek şeklinde değerlendirilebilir. $\mathrm{Bu}$ da 1. Tanımlama (söylem/ metin), 2. Olay örgüsü, 3. Yorum (çözümleme süreci), 4. Açıklama /sonuç (sosyal çözümleme) şeklinde sistematik bir çözümleme sürecini öngörür Eleştirel söylem çözümlemesi süreci, söylemin yeniden inşa sürecidir. Bu süreç neticesinde söylem geniş kapsamda, farklı bir boyutta, yeniden inşa edilerek ortaya konulur. Eleştirel söylem çözümlemesi geniş bir alanı kapsar fakat çoğunlukla politik ve ideolojik 
bir çözümlemedir. Bu çözümleme söylemle ortaya konulan toplumsal olaylar veya toplumsal sorunların çözümlemesidir. Diğer taraftan, eleştirel söylem çözümlemesi, toplumsal yapının ve iktidar ilişkilerinin metindeki izdüşümünü bulmayı amaçlar.

Geçmişte yaşanmış ideolojik siyasi ve sosyokültürel olaylar toplumsal süreç içerisinde bir mücadeleyi ifade ederler. Geçmişte yaşanılan olaylar günümüzle benzerlik gösterdiği bir noktada siyasi ve sosyokültürel bir ilişki kurulur ve buradan hareketle inşa süreci başlar. Tarih içerikli televizyon dizileri ve belgesel filmler sadece tarihî bilgiler vermekle kalmaz aynı zamanda geçmişle günümüz arasında bağlantı kurmak suretiyle uyarıcı bir mesaj niteliği taşır. Böylelikle geçmişte yapılanlar veya yaşananlar gündemde tutulmak suretiyle kolektif bellek inşa edilir. Tarihte yaşanılan olaylar olayları yaşayanların belleğinde saklı olabilir fakat kolektif belleğin inşası yeni nesilleri de hedefler ve böylelikle de sürekliliği sağlanır.

\section{Kaynakça}

AKSAN, D. (2000). Her Yönüyle Dil Ana Çizgileriyle Dilbilim. Ankara: TDK Yayınları.

ALTHUSSER, L. (2000). İdeoloji ve Devletin İdeolojik Aygıtları. İstanbul: İletişim Yayınları.

AYDIN, M. (2007), Dilbilim El Kitabı. İstanbul: 3F Yayınları.

BAL, H. (2012). Nitel Araştırma Yöntemleri. Isparta: Fakülte Kitabevi.

BARTHES, R. (1996). S/Z. Kasar, S, Ö. (Çev.). İstanbul: Ayrıntı Yayınları.

BARTHES, R. (1979). Göstergebilim İlkeleri. Vardar, B, Rıfat., M. (Çev.). Ankara: Kütür Bakanlığı Yayınları.

BEDÜK, N. (2009). Gelenek İktidar İlişkileri ve Cinsiyet Temsillerinde Melezleşme: Türk TV Dizileri Üzerine Bir Söylem Analizi. İstanbul: YL Tezi.

ÇAKIR, C. (2004). Anlamın Bağlam Açısından İncelenmesi: Kökanlambilim ve Artanlambilim. GÜ, Gazi Eğitim Fakültesi Dergisi, Cilt 24, Sayı 3, 245-255.

ÇELIK, H, v.d. (2008). Söylem Analizi. Marmara Üniversitesi Atatürk Eğitim Fakültesi Eğitim Bilimleri Dergisi 99-117.

ÇETIN, M, vd. (2011). Dilde Anlam ve Bağlam. 1st International Conference on Foreign Language Teaching and Applied Linguistics May 5-7, Sarajevo.

EAGLETON, T. (2011). İdeoloji. Özcan, M. (Çev.), İstanbul: Ayrıntı Yayınları.

EBUZEYD, N. H. (2014). Hermenötikve Metin Yorumu. COŞKUN, M. (Çev.), Üniversitesi İlâhiyat Fakültesi Dergisi, Cilt-Sayı 46 • Nisan 2014 • ISSN 1302-4973 • ss. 237-266 • DOI 10.15370/muifd.07141.

ELİOT, T. S. (1983). Edebiyat Üzerine Düşünceler. KANTARCIOĞLU, S. (Çev.), Ankara: Kültür ve Turizm Bakanlığı Yayınları.

ERBİRLIK, T, v.d. (2015). Söylem kuramları bir sınıflandırma çalışması. Dilaraştırmaları, Güz 2015/17: 31-50 S: 47-48.

FOUCOULT, M. (1987). Söylemin Düzeni. ILGAZ, T. (Çev.), İstanbul: Hil Yayın.

FAİRCLOUGH, N. (1995). Critical Discourse Analysis: The Critical Study Of Language. Longman, New York.

FAİRCLOUGH, N, v.d. (1997). Critical discourse analysis. T. Van Dijk(Der.), Discourse 
studies: A multidisciplinary introduction. Vol. 2. (ss. 258-84). London: Sage. FAİRCLOUGH, N. (2001). ) Language and Power (2nd edition), London: Longman.

FAİRCLOUGH, N. (2001). The Dialectics of Discourse in Textus, Vol. 14, No. 2, 231-242.

GÖKA, E, vd. (1999). Önce Söz vardı: Yorumsalcılık Üzerine Bir Deneme. Ankara: Vadi Yayıncılık.

GÜNAY, D. (2013). Söylem Çözümlemesi. İstanbul: Papatya Yayıncılık.

FİSKE, J. (1996) İletişim Çalışmalarına Giriș. Ankara: Cantekin Matbaacılık.

HALL, S. (1998). Anlamlandırma, Temsil, İdeoloji: Althusser ve Postyapısalcı Tartışmalar. Kitle İletişim Kuramları içinde, MUTLU, E, (Der.), Ankara: Ankara Üniversitesi İletişim Fakültesi Yayınları.

JONATHAN, P. (2004). “Söylemsel Psikoloji ve Söylem Analizi.” Doğunun ve Batının Yerelliği içinde. Sibel, A. (Der.), İstanbul: Alfa Kitap.

KIRAN, Z, v.d. (2001). Dilbilimine Giriş. Ankara: Seçkin.

KÖKER, E. (2005). Kitapta Kurutuluş Çiçekler Ya da Sözlü Kültür Üzerine Düşünmek. Ankara: Dipnot Yayınları.

PALMER, (2008). Hermenötik. GÖRENER, İ (Çev.), İstanbul: Ağaç Kitabevi Yayınları.

PHİLLIPS, N, v.d. (2002) Discourse Analysis: Investigation Processes of Social Construction, California: Sage.

RIZVANOĞLU, E. (2012). Nesnellik Arayışı Öznenin Tasfiyesi: Frege ve Wıttgensteın. Düşünme Dergisi / Journal of Thınkıng, Sayı: 2

SAYGIN, T. (2009). Toplumsal Dönüşümler ve Sosyolojik Yaklaşımlar. Aydın: VI. Ulusal Sosyoloji Kongresi, Adnan Menderes Üniversitesi.

SCOLLON, R. (2001).Methods of critical DiscourseAnalysis içinde. Action and text: towards an integrated understanding ofthe place of text in social (inter) action, mediated discourse analysis and the problem of social action.

SÖZEN, E. (1999). Söylem. İstanbul: Paradigma Yayınları.

PARLATIR, İ, v.d. (1998). Türkçe Sözlük. Ankara: TDK.

PORTTER, J. (2004). "Söylemsel Psikoloji ve Söylem Analizi.” Doğunun ve Batının Yerelliği içinde, Sibel A. (Der.), İstanbul: Alfa Kitap.

VAN DİJK, T. A. (2003). Critical discourse analysis. D. Schiffrin., D. Tannen, \& E., H. Hamilton. (Ed.), In The Handbook of Discourse Analysis Oxford: Blakwell Publishing. 352-371.

VARDAR, B. (2002). Açıklamalı Dilbilim Terimleri Sözlüğü. İstanbul: Multilingual yayınları.

W00D, L, v.d. (2000). Doing Discourse Analysis: Methods for Studying Action in Talk and Text, California: Sage :78. 
